\title{
Research on Motivating Factors of the Transformation from Business Enterprise to Social Enterprise
}

\author{
Jianhua Wu, Saichao Chang, Shenglin Jiang \\ School of Business Administration, South China University of Technology, Guangzhou, China \\ Email: jianhua_wu0109@163.com,1561727494@qq.com
}

How to cite this paper: $\mathrm{Wu}, \mathrm{J} . \mathrm{H} .$, Chang, S.C. and Jiang, S.L. (2017) Research on Motivating Factors of the Transformation from Business Enterprise to Social Enterprise. American Journal of Industrial and Business Management, 7, 1285-1297. https://doi.org/10.4236/ajibm.2017.712091

Received: November 30, 2017 Accepted: December 12, 2017 Published: December 15, 2017

Copyright ( 92017 by authors and Scientific Research Publishing Inc. This work is licensed under the Creative Commons Attribution International License (CC BY 4.0).

http://creativecommons.org/licenses/by/4.0/

\begin{abstract}
The social enterprise arouses during the exploration of new welfare system by the western welfare states in 1970s. It was stemmed from the basis of non-profit organization and related to solving unemployment problems. The time for our country to accept the concept of social enterprise came later. In general, the social practice and theory study of social enterprise for our country are still at an early stage. This paper selected the transformation of commercial enterprise to social enterprise to be the topic of discussion, and explored the motivation factors started by case studies, which aimed at enriching the study in the field of social enterprise in our country.
\end{abstract}

\section{Keywords}

Social Enterprise, Business Enterprise, Entrepreneur, Cultural Traditions, Government Support, Social Concern

\section{Introduction}

The idea of social enterprise originated from the socio-economy concept brought up by the French economist Thierry Jeantay (1998). And then in 1999 the Organization for Economic Cooperation and Development of Europe (OECD) gave the concrete definition-the social enterprise is an organization not just in pursuit of profit maximization mainly but also involves in any kinds of private activities to generate public interest, to develop a strategy for specific economic or social goals, as well as to help resolve social discrimination and unemployment issues.

In this paper, we believe that social enterprise is a form between traditional non-profit organization and commercial enterprise, which is an extension to the 
traditional non-profit organization model and is also an innovation of commercial enterprise. From the perspective of organization structure, if an organization is divided into political organization (the Party), administrative organization (the Government), profit organization (the Enterprise), charitable organization (the Community), then social enterprise should land between the Enterprise and the Community. On one hand, the social enterprise is on the edge of the Enterprise categorization, and on the other, it is on the edge of the community or pure charity; therefore, it's connected to both types of the organizations, and it has a character of connectivity. (Shi Lirong, 2005) [1]. Some of the social enterprises and their typical behaviors are introduced in Table 1.

\section{Research and Design}

\subsection{Research Methods}

This paper applied the grounded theory to case study and the essence of this theory is to study cases. This research method of rooted theory is a process of continuous comparing, thinking, analyzing and transforming information into concept to establish theory. It is a dynamic research process, which has its own rigid procedures and steps. Through the discussion on various literature, selection of specific case, collection and reorganization of the information, coding on different materials and all to come to a conclusion that can passed through the test on the completeness of the theory. Only then can the conclusion been finalized.

\subsection{Case Selection}

The purpose of this paper is to explore the motion and mechanism for the transformation of commercial enterprises to social enterprises. The case selection criteria are as follows: 1) selected enterprises are social enterprises or its development indicate some characteristics of social enterprises; 2) selected enterprises

Table 1. Part of the social enterprise and its typical behavior.

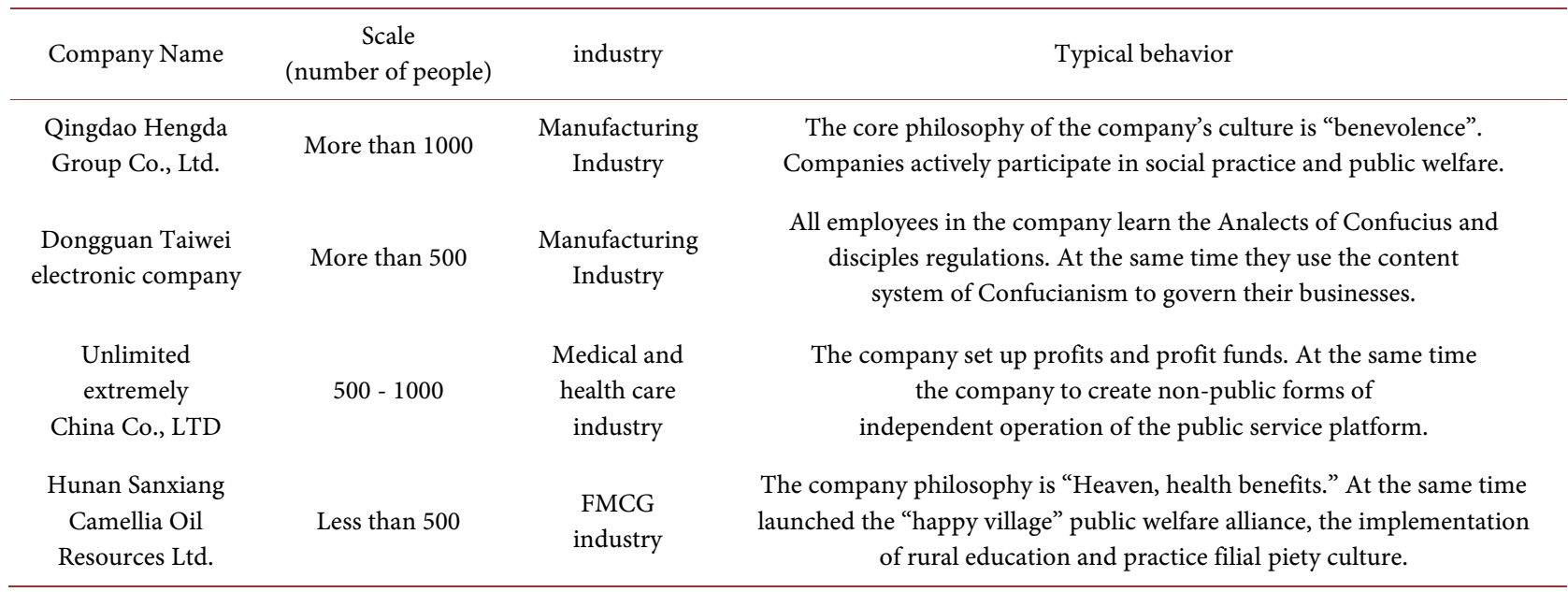

Data sources: the study was collected and arranged. 
are in conformity with the development path from commercial enterprises to social enterprises; 3 ) accessibility of information. Finally one typical case was selected despite of limited options. The general background information of the selected case is introduced in Table 2.

\subsection{Data Collection}

In order to ensure the reliability of data, this study chooses a variety of methods and multiple channels to obtain the information. All information in this case study is mainly through the collection of primary data and second-hand data. The primary data is obtained through interviews and filtering interview information. Second-hand data is mainly collected through three sources: firstly, the direct information from the company involved; secondly, internet information; thirdly, business cases.

More than a dozen companies such as Qingdao Hengda, Da Sanxiang and Infinite Pole visited by the research team provided more choices for the theoretical sampling of this article. During the interviews, the interviewer should adjust to the state of empathy, place himself in empathy, pay attention to the questions that the interviewee cares about, and listen to the phenomenon that the interviewee mainly describes and the reason behind the phenomenon. In order to make the respondents say their true thoughts, the interview process should make full use of the openness issue, try to avoid the interviewers from exerting psychological pressure, and finish the interview in a talkative way. The research team, through prior consultation with the relevant materials and communication, has a certain degree of familiarity with the companies studied. According to the research directions, the research team designs the interview outline to further the enterprise, conduct in-depth interviews with employees and leaders, and obtain information during the visit, a lot of internal information. Research team members work together to transcribe collected transcripts into verbatim transcription; artificially input photos-based texts and paper texts into word documents. After finishing, a total of about 280,000 words of first-hand information and a total of about 370,000 words of second-hand information were taken, a number of photos and videos were taken, which provided a solid data foundation for rooted research.

Table 2. Case introduction.

\begin{tabular}{cl}
\hline Company Name & \multicolumn{1}{c}{ Case Introduction } \\
\hline & Tai Wei Electronics Co., Ltd. was founded in 1997. It is a commercial enterprise dedicates to the \\
R\&D, manufacturing and sales of mobile phones, audio-visual products, MID and connectors for \\
electronic devices. Under the leadership of chairman Wenliang Li, this company was led to a \\
development of a social enterprise with the establishment of a specific education center and \\
a humanity center. The core work of the education Center is to promote the popularization of \\
Chinese traditional culture. The centric of the humanity center is to help farmers with difficulties \\
in production and sales to add values and generate additional revenue.
\end{tabular}

Data sources: the study was collected and arranged. 


\section{Data Analysis}

\subsection{The Single Case Analysis of Taiwei Company}

\subsubsection{Open Coding}

Open coding refers to the process of decomposing, viewing, comparing, conceptualizing, and categorizing data (Strauss \& Corbin, 1997) [2], which is a process of breaking down the data and then reassembling the information in a new way(Chen Xiangming, 2000) [3]. In this paper, according to the process of open coding, Taiwei company's data were encoded. Open coding examples of the reasons for the social activities of the Taiwei Company are listed in Table 3.

We have conducted open coding on the interview records, internal document and internet information, from which we got 107 the third noded (label), 38 the second noded (conceptualization), and 16 the first noded (categorization). The first and second nodes are listed in Table 4.

\subsubsection{Spindle Encoding}

Through the open coding method, we got 16 categorized concepts, which were to be re-classified again by grouping similar ones. This time we got 4 major influential factors that contribute to the transformation of the commercial enterprise to social enterprise, which are namely personal influence of the entrepreneurs, the influence of the culture, the promotion of government, the drive from social demand, as shown in Table 5.

Table 3. Open coding example of the reasons for the social activities of the Taiwei company.

\begin{tabular}{|c|c|c|c|}
\hline Case information & Labeling & Conceptualization & Categorization \\
\hline $\begin{array}{l}\text { "My growth was cultivated by many people, } \\
\text { and I want to inherit and pass on this cultivation } \\
\text { mechanism and also the benefits I get." }\end{array}$ & $\begin{array}{l}\text { a1: Business is a } \\
\text { channel for inheriting } \\
\text { the morality and justice }\end{array}$ & $\begin{array}{l}\text { A1: Appreciation } \\
\text { and gratitude }\end{array}$ & \\
\hline $\begin{array}{l}\text { Entrepreneurs have a sense of social responsibility. } \\
\text { If we have the ability to help our parents, families, } \\
\text { and the society then we shall contribute to them. }\end{array}$ & $\begin{array}{l}\text { a7: Have a sense of } \\
\text { responsibility for } \\
\text { the society }\end{array}$ & A3: Social responsibility & AA1: Entrepreneurial passion \\
\hline \multicolumn{4}{|l|}{ There are 19 similar records. } \\
\hline $\begin{array}{l}\text { "Now we welcome the government to } \\
\text { investigate into our problems." }\end{array}$ & $\begin{array}{l}\text { a90: Government's } \\
\text { supervision can } \\
\text { promote business growth }\end{array}$ & $\begin{array}{l}\text { A34: The encouragement } \\
\text { and supervision of } \\
\text { the government }\end{array}$ & $\begin{array}{l}\text { AA14: The Promotion } \\
\text { of government supervision }\end{array}$ \\
\hline \multicolumn{4}{|l|}{ There are 6 similar records. } \\
\hline $\begin{array}{l}\text { In } 2013 \text {, sensing that college education was } \\
\text { disconnected with the reality, I promoted the } \\
\text { idea of everyone to join the self-taught } \\
\text { higher education examinations. }\end{array}$ & $\begin{array}{l}\text { a97: Dissatisfied } \\
\text { with the current } \\
\text { education situation }\end{array}$ & $\begin{array}{l}\text { A36: Dissatisfied } \\
\text { with the current } \\
\text { education situation }\end{array}$ & $\begin{array}{l}\text { society and the discovery } \\
\text { of social problems }\end{array}$ \\
\hline $\begin{array}{l}\text { The entire society generally admires the sense } \\
\text { of responsibility, which indicates the enterprise to } \\
\text { take on the responsibility and adapt to this trend. }\end{array}$ & $\begin{array}{l}\text { a105: The promoting } \\
\text { of corporate social } \\
\text { responsibility }\end{array}$ & $\begin{array}{l}\text { A38: The motivation } \\
\text { from the society and trend }\end{array}$ & $\begin{array}{l}\text { AA16: The promotion } \\
\text { of social environment } \\
\text { and social trends }\end{array}$ \\
\hline
\end{tabular}

Data sources: the study was collected and arranged. 
Table 4. The first level node and the second level node.

\begin{tabular}{|c|c|c|c|c|c|}
\hline The second level node & $\begin{array}{l}\text { The first } \\
\text { level node }\end{array}$ & $\begin{array}{l}\text { The second } \\
\text { level node }\end{array}$ & $\begin{array}{l}\text { The first } \\
\text { level node }\end{array}$ & $\begin{array}{l}\text { The second } \\
\text { level node }\end{array}$ & $\begin{array}{l}\text { The first } \\
\text { level node }\end{array}$ \\
\hline $\begin{array}{l}\text { A1: Gratitude \& } \\
\text { appreciation } \\
\text { to the society }\end{array}$ & \multicolumn{3}{|c|}{ A15: Perseverance } & $\begin{array}{l}\text { A27: Celebrity } \\
\text { models of humanity }\end{array}$ & \multirow{3}{*}{$\begin{array}{l}\text { AA10: The influence } \\
\text { of celebrity model }\end{array}$} \\
\hline A2: Patriotism & \multirow{4}{*}{$\begin{array}{l}\text { AA1: } \\
\text { Entrepreneur's spirit }\end{array}$} & A16: Unfettered & & $\begin{array}{l}\text { A28: Successful } \\
\text { entrepreneur }\end{array}$ & \\
\hline $\begin{array}{l}\text { A3: Social } \\
\text { Responsibility }\end{array}$ & & $\begin{array}{l}\text { A17: } \\
\text { Challenge spirit }\end{array}$ & $\begin{array}{l}\text { AA5: } \\
\text { Entrepreneur's } \\
\text { personality }\end{array}$ & $\begin{array}{l}\text { A29: Successful } \\
\text { business model }\end{array}$ & \\
\hline $\begin{array}{l}\text { A4: A sense of } \\
\text { ethnic responsibility }\end{array}$ & & $\begin{array}{l}\text { A18: } \\
\text { Full confidence }\end{array}$ & & A30: Buddhism & \multirow{2}{*}{$\begin{array}{l}\text { AA11: The influence } \\
\text { of religious culture }\end{array}$} \\
\hline $\begin{array}{l}\text { A5: A sense of } \\
\text { charitable contribution }\end{array}$ & & A19: Decisiveness & & A31: Confucianism & \\
\hline A6: Faith and believes & \multirow{3}{*}{$\begin{array}{l}\text { AA2: } \\
\text { Entrepreneur's belief }\end{array}$} & $\begin{array}{l}\text { A20: } \\
\text { Social sensitivity }\end{array}$ & & $\begin{array}{l}\text { A32: The mutually } \\
\text { dependent } \\
\text { relationship } \\
\text { between government } \\
\text { and enterprise }\end{array}$ & $\begin{array}{l}\text { AA12: The mutually } \\
\text { dependent relationship } \\
\text { between government } \\
\text { and enterprise }\end{array}$ \\
\hline A7: Buddhism & & $\begin{array}{l}\text { A21:External } \\
\text { demand sensitivity }\end{array}$ & $\begin{array}{l}\text { AA6: } \\
\text { Entrepreneur's } \\
\text { acumen }\end{array}$ & $\begin{array}{l}\text { A33: } \\
\text { Acknowledgement } \\
\text { to the entrepreneur } \\
\text { reputation by the } \\
\text { government }\end{array}$ & $\begin{array}{l}\text { AA13: } \\
\text { Acknowledgement } \\
\text { to the entrepreneur } \\
\text { reputation by } \\
\text { the government }\end{array}$ \\
\hline $\begin{array}{l}\text { A8: Confucian } \\
\text { cultural belief }\end{array}$ & & $\begin{array}{l}\text { A22: Enterprise } \\
\text { development } \\
\text { strategy sensitivity }\end{array}$ & & $\begin{array}{l}\text { A34: Government's } \\
\text { promotion and } \\
\text { supervision }\end{array}$ & $\begin{array}{l}\text { AA14: Government's } \\
\text { promotion and } \\
\text { supervision }\end{array}$ \\
\hline A9: The speed of action & & $\begin{array}{l}\text { A23: The Influence } \\
\text { of Confucianism } \\
\text { on Enterprise } \\
\text { Development }\end{array}$ & $\begin{array}{l}\text { AA7: } \\
\text { The influence of } \\
\text { culture and } \\
\text { traditions }\end{array}$ & $\begin{array}{l}\text { A35: Concerns } \\
\text { about the } \\
\text { deterioration } \\
\text { of adolescents }\end{array}$ & \multirow{2}{*}{$\begin{array}{l}\text { AA15: Reflections on the } \\
\text { status quo of society } \\
\text { and the discovery } \\
\text { of problems in society }\end{array}$} \\
\hline A10: Mandatory action & $\begin{array}{l}\text { AA3: } \\
\text { Entrepreneur's action }\end{array}$ & $\begin{array}{l}\text { A24: } \\
\text { Local customs } \\
\text { and rituals }\end{array}$ & $\begin{array}{l}\text { AA8: } \\
\text { Cultural customs }\end{array}$ & $\begin{array}{l}\text { A36: Dissatisfaction } \\
\text { with the status } \\
\text { quo of education }\end{array}$ & \\
\hline A11: Direction of action & & $\begin{array}{l}\text { A25: Chinese } \\
\text { literature classics }\end{array}$ & \multirow{4}{*}{$\begin{array}{l}\text { AA9: } \\
\text { classic ideas }\end{array}$} & $\begin{array}{l}\text { A37: Concerns } \\
\text { about food safety }\end{array}$ & \multirow{4}{*}{$\begin{array}{l}\text { AA16: The drive of } \\
\text { social environment } \\
\text { and social trends }\end{array}$} \\
\hline A12: Background & AA4:Entrepreneur's & $\begin{array}{l}\text { A26: Foreign } \\
\text { classic books }\end{array}$ & & $\begin{array}{l}\text { A38: The drive of } \\
\text { social environment } \\
\text { and social trends }\end{array}$ & \\
\hline $\begin{array}{l}\text { A13: The promoted } \\
\text { cultural values }\end{array}$ & $\begin{array}{l}\text { knowledge } \\
\text { and education }\end{array}$ & & & & \\
\hline $\begin{array}{l}\text { A14: Disagreed } \\
\text { cultural perspective }\end{array}$ & & & & & \\
\hline
\end{tabular}

Data sources: the study was collected and arranged.

Spindle coding method connects different paradigms with the Paradigm Model, which is "condition-action-result" (Corbin \& Strauss, 1990; Zhou Jianghua et al., 2012) [4] [5]. The spindle coding results are shown in Table 6. 
Table 5. Core concepts categorization from the open coding results.

\begin{tabular}{lc}
\hline \multicolumn{1}{c}{ Categories } & Core Categories \\
\hline AA1: Entrepreneur's spirit & \\
AA2: Entrepreneur's belief & The influence \\
AA3: Entrepreneur's action & of the entrepreneur \\
AA4: Entrepreneur's personality & \\
AA5: Entrepreneur knowledge and education & The influence \\
AA6: Entrepreneur's acumen & of culture \\
AA7: The influence of traditional culture & \\
AA8: The impact of local customs and rituals & \\
AA9: The touch of classics & The promotion \\
AA10: The model effect of celebrities & of government \\
AA11: The influence of religious culture & \\
AA12: The mutually dependent relationship between & The drive of \\
government and enterprise & social demand \\
AA13: Government's recognition of enterprise's reputation & \\
AA14: Government's promotion and supervision & \\
AA15: Reflections on the status quo of society and the & \\
discovery of problems in society & \\
AA16: The drive from social environment and social trends &
\end{tabular}

Data sources: the study was collected and arranged.

Table 6. Spindle coding results.

\begin{tabular}{|c|c|c|c|}
\hline Conditions & Behaviors & Results & Categories \\
\hline $\begin{array}{l}\text { Entrepreneurs have decisive character, } \\
\text { challenging spirit, toughness, } \\
\text { and maybe a little stubborn. }\end{array}$ & $\begin{array}{l}\text { Entrepreneurs ignore the objections } \\
\text { from the board of directors } \\
\text { regarding business transformation. }\end{array}$ & $\begin{array}{l}\text { Commercial enterprise continues } \\
\text { to develop into social enterprise. }\end{array}$ & $\begin{array}{l}\text { Entrepreneur } \\
\text { personality factor. }\end{array}$ \\
\hline $\begin{array}{l}\text { Entrepreneurs can keenly capture the } \\
\text { social problems and the needs of the } \\
\text { community and employees, and } \\
\text { he has a strong motivation on action. }\end{array}$ & $\begin{array}{l}\text { Entrepreneur promotes the education } \\
\text { of traditional culture, and requires } \\
\text { employees to learn the book The } \\
\text { Disciples, as well as encourage the } \\
\text { spread of humanity like } \\
\text { pollution-free plantation. }\end{array}$ & $\begin{array}{l}\text { The needs of employees have } \\
\text { been met, the enterprise within a } \\
\text { certain range to solve some of the } \\
\text { social problems, such as education, } \\
\text { food safety issues. }\end{array}$ & $\begin{array}{l}\text { The Influence of } \\
\text { Society Factors on } \\
\text { Entrepreneurs. }\end{array}$ \\
\hline $\begin{array}{l}\text { Confucianism emphasizes more on } \\
\text { justice than benefits, which is } \\
\text { advocated by entrepreneurs. }\end{array}$ & $\begin{array}{l}\text { Entrepreneurs prefer } \\
\text { justice to benefits. }\end{array}$ & $\begin{array}{l}\text { Entrepreneurs are mainly } \\
\text { responsible for the propaganda } \\
\text { of culture and education. }\end{array}$ & $\begin{array}{l}\text { The Influence of } \\
\text { Cultural Factors } \\
\text { on Entrepreneurs. }\end{array}$ \\
\hline $\begin{array}{l}\text { Entrepreneurs follow Buddhism, } \\
\text { and believe casual effects } \\
\text { as well as charitable contribution. }\end{array}$ & $\begin{array}{l}\text { Entrepreneur integrates the causal } \\
\text { effect concept into the corporate } \\
\text { culture, and the entrepreneur cares } \\
\text { about the staff and the community. }\end{array}$ & $\begin{array}{l}\text { The corporate culture advocates } \\
\text { the concept of causal effect, opens a } \\
\text { Tong Meng Museum, and a training } \\
\text { camp of original point method. }\end{array}$ & $\begin{array}{l}\text { The factor of } \\
\text { entrepreneur's } \\
\text { belief. }\end{array}$ \\
\hline $\begin{array}{l}\text { The government rewards and } \\
\text { acknowledges social enterprise } \\
\text { for the activities that indicate } \\
\text { a social responsibility. }\end{array}$ & $\begin{array}{l}\text { Entrepreneurs are encouraged, } \\
\text { more conducive to accept } \\
\text { government supervision. }\end{array}$ & $\begin{array}{l}\text { Entrepreneurs decided to continue } \\
\text { to vigorously promote social } \\
\text { activities, and based it on } \\
\text { regular business operations. }\end{array}$ & $\begin{array}{l}\text { The Influence of } \\
\text { Government on } \\
\text { Entrepreneurs. }\end{array}$ \\
\hline
\end{tabular}

Data sources: the study was collected and arranged.

Through the spindle coding, we found that there are four factors connected through open coding, which will promote the development of enterprises by the business enterprises for the social enterprises. The entrepreneur's tenacity, bold 
action, keen interest in traditional culture and religious influence play a leading role in the transformation of the enterprise. The government, social and cultural factors will have an impact on the entrepreneur in some way and strengthen the entrepreneurial commitment to social undertakings.

\subsubsection{Selective Coding}

Selective decoding is to select the core categories, and then to connect them systematically with other categories, and then to verify the internal relationships, as well as to expand the list of categories until complete (Strauss, Corbin, 1997) [2].

As the most direct tool for the entrepreneur is his company, we conducted research from the company internally to explore the motivation mechanism. The best core element of the company are the employee and team, therefore we started from three perspectives to discuss the motivation mechanism, which are the entrepreneurs, employees and organizations. The results of the selective coding are shown in Table 7.

We analyzed the results of the selective coding, and got the following story line: The entrepreneur of Taiwei Company has the absolute control of the enterprise, whose decision determines the development direction of the development of enterprises. The entrepreneur was deeply influenced by the cultural environment, and believes in Buddhism as well as causal effect (Karma). He admires Confucian, and understands the assimilation impact from the book The Disciples on his employees' physical and mental development. Therefore he decided to promote the study of traditional Chinese culture, and then immerse its core culture value, like Karma, respecting the elder families, creditability and justice as well as philanthropism, into corporate culture. The idea of Karma encourages entrepreneurs to do more good to the community to benefit the society. At the same time, the entrepreneur is keen to capture the social problems like education issue and food safety issue. He thoroughly emphasized the need of his employees to take care of children and the elderly. As he himself is strongly self-motivated and proactive, he encouraged the employee and the community to promote traditional culture together, and to develop eco-agriculture. The entrepreneur was enlightened by a respected senior Buddhist monk that developing the business should serve the society, which reinforced his determination to continue on the path transforming to social enterprise.

\section{Research Findings}

\subsection{The Dominant Role of the Entrepreneur}

As a leader in the transformation process of commercial enterprise into social enterprise, the entrepreneur is in the absolute dominant position in corporate operation. Whether an entrepreneur can become a social entrepreneur depends on his human capital and personal will, as well as opportunities in society. When these three conditions are met at the same time, this person is likely to carry out the practice of social entrepreneurs. So we can say that individual factors are the prerequisite for becoming a social entrepreneur. The board of director in Taiwei 
Table 7. Selective coding results.

\begin{tabular}{|c|c|c|c|}
\hline Object of study & Conditions & Behaviors & Results \\
\hline $\begin{array}{l}\text { The } \\
\text { entrepreneur }\end{array}$ & $\begin{array}{l}\text { 1) Entrepreneurial personal factors: } \\
\text { a) Personalities: Love challenges, } \\
\text { decisive, sensitive, and action-oriented } \\
\text { b) Culture beliefs: faith in Buddhism, } \\
\text { firmly believed in causal effect, } \\
\text { enthusiastic about Chinese } \\
\text { traditional culture, strong sense } \\
\text { of social responsibility } \\
\text { 2) The impact of the external } \\
\text { environment on entrepreneurs: } \\
\text { a) The government recognizes and } \\
\text { appraises the corporate reputation. } \\
\text { b) The existence of social problems like } \\
\text { food safety issues and children's education } \\
\text { issues arouse entrepreneur's concerns. } \\
\text { c) Celebrity's modeling effect. }\end{array}$ & $\begin{array}{l}\text { 1) Reconstructing organizational } \\
\text { structure by establishing a specific } \\
\text { education department and a } \\
\text { morality and justice department. } \\
\text { 2) Promoting activities about } \\
\text { education and culture } \\
\text { a) Organizing internal events } \\
\text { about learning traditional culture } \\
\text { b) Requiring employees to join the } \\
\text { self-taught higher education } \\
\text { examinations } \\
\text { c) Organizing lectures on culture and } \\
\text { specifically traditional Chinese culture } \\
\text { 3) The establishment of } \\
\text { ecological agriculture } \\
\text { a) Self-growing pollution-free crops } \\
\text { b) Supporting farmers on plantation. }\end{array}$ & $\begin{array}{l}\text { 1) The entrepreneur himself } \\
\text { becomes a social entrepreneur } \\
\text { 2) He promotes changes in } \\
\text { organizational structure } \\
\text { 3) He help farmers improve } \\
\text { living conditions } \\
\text { 4) His employees can enjoy } \\
\text { pollution-free fruits and vegetables. }\end{array}$ \\
\hline Employee & $\begin{array}{l}\text { 1) It's required for employees to } \\
\text { learn traditional Chinese culture } \\
\text { 2) Continued study is needed as } \\
\text { they are not highly educated } \\
\text { 3) It's needed to be able to work } \\
\text { in company and satisfy life demands. }\end{array}$ & $\begin{array}{l}\text { 1) Participating self-taught } \\
\text { higher education examinations } \\
\text { 2) Participating training classes } \\
\text { on traditional culture and } \\
\text { specific Chinese culture. } \\
\text { 3) Promoting corporate } \\
\text { cultural activities to the community } \\
\text { 4) Participating activities to establish } \\
\text { eco-agricultural construction, like } \\
\text { planting pollution-free fruits and } \\
\text { vegetables to help farmers sell apples. }\end{array}$ & $\begin{array}{l}\text { Employee participated cultural stu- } \\
\text { dies, and agreed with the } \\
\text { corporate culture } \\
\text { Employee's education was } \\
\text { improved and some of them } \\
\text { got the degree through self-taught } \\
\text { education exams. } \\
\text { Recognizing and supporting } \\
\text { enterprise to transform } \\
\text { into social enterprise } \\
\text { Voluntarily participating } \\
\text { community events. }\end{array}$ \\
\hline Organization & $\begin{array}{l}\text { 1) Entrepreneurs are determined } \\
\text { to establish social enterprise. } \\
\text { 2) Entrepreneurs promote organizational } \\
\text { restructuring } \\
\text { 3) Employees improved their awareness } \\
\text { and enhanced social responsibility } \\
\text { 4) Employees agreed to promote } \\
\text { social enterprise } \\
\text { 5) Employees actively participate } \\
\text { in community events } \\
\text { 6) Entrepreneurs and employees } \\
\text { need to follow the new } \\
\text { corporate rules and regulations. }\end{array}$ & $\begin{array}{l}\text { 1) A specific education department } \\
\text { as well as a humanity and justice } \\
\text { department is established. } \\
\text { 2) New regulations were added to } \\
\text { promote traditional culture. } \\
\text { 3) Traditional culture was } \\
\text { publicized in the company. }\end{array}$ & $\begin{array}{l}\text { After the changes in } \\
\text { organizational structure } \\
\text { and regulations, the ultimate } \\
\text { goal of the enterprise is to } \\
\text { transform into social enterprise. }\end{array}$ \\
\hline
\end{tabular}

Data sources: the study was collected and arranged.

Company advocates Confusion and has their own unique perspective on Chinese traditional culture. They proactively immerse the traditional culture into corporate management and advocate Chinese management philosophy. According to the above, proposition 1 is proposed.

H1: Entrepreneurs are the key factors to promote the transformation of enterprises to social enterprises. The reason is that entrepreneur's specific culture belief or ideas are the motivation promoting the transformation. When the en- 
trepreneur takes the socialization as the goal of developing the corporate, and adopts firm confidence, perseverance, and decisive action, his enterprise then has the possibility to develop as a social enterprise. At the same time he has the foundation of becoming a social entrepreneur.

\subsection{The Influence of Cultural Traditions}

The essence of Chinese traditional culture has always included the charitable spirit of contributing to the society. According to this, proposition 2 is proposed.

H2: The charitable spirit and world sentiment contained in Chinese traditional culture laid the cultural foundation for the social purpose of the enterprise. Confucian respected righteousness before benefit. The theory of Karma respected by Buddhism is believed by entrepreneurs, and it is also the root in respective of culture to motivate entrepreneurs to change from pursuing maximized benefits to a society-oriented concepts.

\subsection{Government Support}

The government is a strong support to advocate corporate taking on social responsibility. Through operating the business whole-heartedly, maximizing the influence, enhancing the cooperation with the government, the enterprise can gain acknowledgement and support from the public and the government to keep building a resource connection between social enterprise and the government. This is very crucial to the self-development of the enterprise.

Accordingly, this paper puts forward proposition 3.

H3: The government's affirmation of corporate behavior and the supervision by government are the external motivations for the enterprises to adhere to the development path of social enterprises. Government financial funding and technical support are the conditions for the development of social enterprises. When entrepreneurs feel the affirmation and support from the government, they will firmly develop the enterprise's confidence in the social enterprise.

\subsection{Social Concern}

The fulfillment of corporate social responsibility will acquire public recognition, thus the public trust, which can generate great financial benefits. Thus there will be more enterprises change from passive to proactive, fulfilling social responsibility, investing into public welfares.

The external dynamic factor of society is embodied in three aspects. Firstly, the existing bad phenomenon in the society has aroused the dissatisfaction of the social entrepreneur and the determination to change this situation. Secondly, the level of the public recognition and trust of the social may affect the development of social enterprise. Thirdly, the needs of the society and the community provide a development direction for social enterprises. Accordingly, this paper puts forward proposition 4.

H4: The development of corporate social responsibility has prompted more 
and more enterprises to develop into social enterprises, when entrepreneurs find the need for social responsibility development and have the resolve to solve social problems; enterprises have the possibility of developing into social enterprises.

By analyzing the case, we found that the government, society, culture and other external environmental factors can influence entrepreneurs' mindset and management ideas, which turns their behavior and even impact the development of the corporate. When the enterprise adopts the concept of charitable contribution to the public, then it's likely for his enterprise to develop into a social enterprise. Through the case study, we believe that entrepreneurs are the key factor contributing to the transformation of enterprises to social enterprises. Entrepreneur's personality, management philosophies, culture orientation, and action collectively decide whether the enterprise can become a social enterprise. This paper proposes a dynamic factor model of commercial enterprises becoming social enterprises. See Figure 1.

\section{Research Conclusions}

Through the above description of the case and the analysis of the influencing factors, we summarize the dynamic factors that affect the development of a firm from traditional commercial enterprise to social enterprise, including internal factors and external factors. Among them, the internal factors mainly refer to the entrepreneur factors and the external factors include the government factors, social factors, cultural traditions. Entrepreneurship is the key factor to promote the transformation of enterprises. Entrepreneurs' personality, business philosophy, cultural orientation and mobility determine whether an enterprise can develop into a social enterprise. Without the existence of social entrepreneurs, or enterprises do not have the spirit of social entrepreneurs leader, then even with the government, the market, social and other external factors, enterprises also

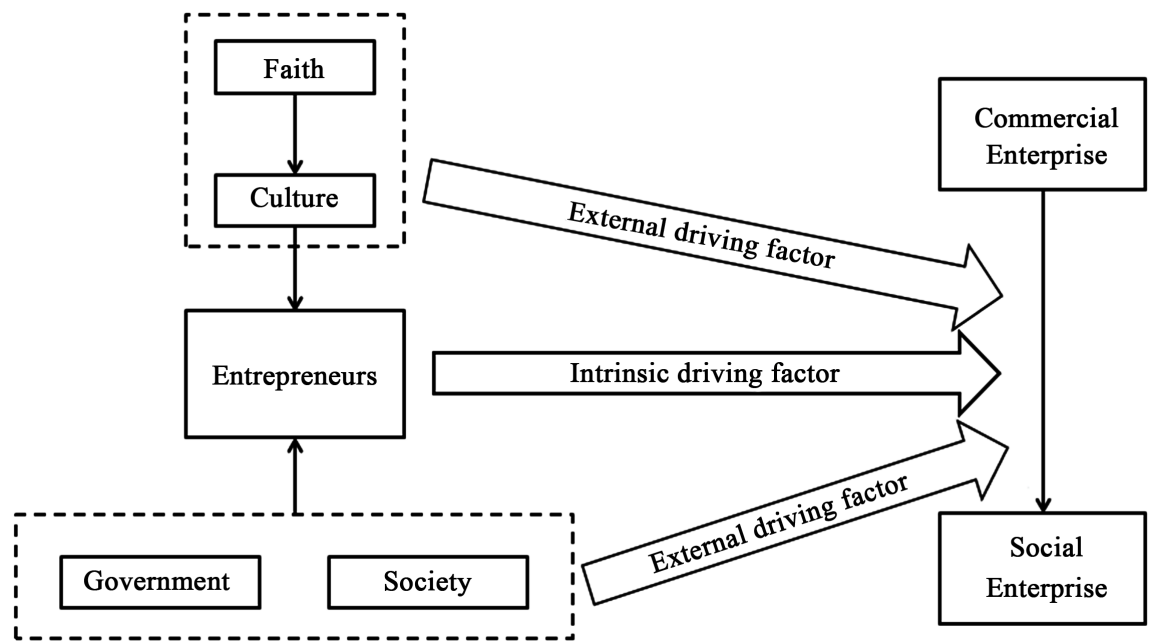

Figure 1. The dynamic factors of commercial enterprises to the development of social enterprises. 
lack the opportunity to change from commercial enterprises to social enterprises. External environmental factors such as government, society and culture influence entrepreneur's behavior by influencing entrepreneur's ideology and philosophy, so as to affect the development direction of the enterprise. Among the external factors, the traditional cultural factors are the factors that are most closely linked with the factors of social entrepreneurs and the most direct drivers for entrepreneurs to lead the enterprises to the path of social enterprises. Other external factors also provide the environment and support for internal factors. If enterprises have the social entrepreneurial factors, then they have the possibility of transition to social enterprises; if on this basis and they have other external factors, then the transition will be much smoother.

At the same time, we also found in the process of case analysis that after entrepreneurs have the will to solve a certain social problem, they organize related social activities within the enterprise to encourage and attract employees to participate actively. Entrepreneurs and employees jointly promote local changes in the organization of an enterprise, such as improving the organizational structure and organizational institution of the enterprise, enabling the enterprise to better embody the characteristics of solving a social problem as its fundamental objective and more of a characteristic of a social enterprise. Accordingly, this paper proposes the motive mechanism for the transformation of commercial enterprises to social enterprises.

\section{Enlightenment}

By analyzing the case of the transforming commercial enterprises into social enterprises, this paper constructs a dynamic factor model of business enterprise into a social enterprise. We get the following take-away for management:

1) To promote Chinese culture and to create a culture atmosphere of charitable contribution to the society

The Confucianism and Taoism of Chinese culture contain lots of charitable spirit, which lays a foundation for the benevolence of Chinese contemporary entrepreneur. Therefore, we need to advocate Chinese traditional culture in the entire society, publicizing the idea of preferring righteousness to benefits as well as Karma in Confusion and Buddhism. This will encourage more and more entrepreneurs to take up the courage to contribute the society. We will see more and more social entrepreneurs and the culture of contribution is hence enforced.

2) To strengthen the spirit of entrepreneurship and cultivate more social entrepreneurs

By carrying out traditional culture education, we can find and inspire the good thoughts of entrepreneurs. Meantime, it can create more social entrepreneurs. It can raise the awareness of social enterprises in commercial enterprises, especially through strengthening the education of entrepreneurial ideas. Businesses can embed CSR into business relationships, including volunteering, charitable donations, and mentoring other businesses, through the practical social 
activities, the commercial enterprises to the development of social enterprises.

3) To increase public awareness of the social enterprise

The success of social enterprises lies in citizen's understanding and active participation. The products and service of social enterprises can be realized only after being purchased. The needs of the public provide a direction for social enterprise to offer service. At the same time, it is also the driver to promote the transformation from commercial enterprises into social enterprises. We need to improve the public recognition of social enterprises, to set up the right environment for the enterprises' transformation to social enterprises.

\section{Research Limitations and Future Research Directions}

This article mainly relies on the observation and perception of the interviewed managers, the interviewed interviewees' words, and the fieldwork and perceptions of the researchers to judge motive mechanism for the transformation of commercial enterprises to social enterprises without using large sample data to show whether there is a significant overall improvement in employee self-regulation. We hope there will be more case studies in the future, and on the basis of these case studies, relevant scales can be developed so that there will be more relevant studies based on the measurement of the motive mechanism for the transformation of commercial enterprises to social enterprises.

As with all the articles that use the rooting theory, this article is inevitably affected by the author's own subjective influence. In order to ensure the objectivity, normality and rigor of the study, this article obtains the one-hand interview data as much as possible in the collection of the case data stage, and collects the secondary data from various channels as far as possible.

\section{Acknowledgements}

Grateful acknowledgement is made to my supervisor Professor Chao Gang who gave me considerable help by means of suggestion, comments and criticism. His encouragement and unwavering support has sustained me through frustration and depression. Without his pushing me ahead, the completion of this article would be impossible. And this thesis is supported by the National Natural Science Foundation of China (Grant No. 71572060 and 71672062).

\section{References}

[1] Shi, L.R. (2005) From Informal Employment Organizations to Social Enterprises. Academic Journals, No. 9, 42-44.

[2] Strauss, A.L. and Corbin, J.M. (1997) Grounded Theory in Practice: A Collection of Readings. 295-296.

[3] Chen, X.M. (2000) Qualitative Research Methods and Social Science Research. Educational Science Press, 332-336.

[4] Zhou, J.H., Quan, Y.H. and Li, G.J. (2012) Based on the Disruptive Innovation of the Pyramid Bottom (BOP) Market-A Case Study of the Cottage Industry. Management World, 2, 34-42. 
[5] Corbin, J. and Strauss, A. (1990) Grounded Theory Research: Procedures, Canons and Evaluative Criteria. Qualitative Sociology, 13, 3-21.

https://doi.org/10.1007/BF00988593 